\title{
Proactive policing: limiting the role of the defence lawyer
}

Citation for published version (APA):

Cape, E., \& Spronken, T. (1998). Proactive policing: limiting the role of the defence lawyer. In S. Field, \& C. Pelser (Eds.), Invading the Private: State Accountability and New Investigative Methods in Europe (pp. 291-322). Dartmouth Publishing Co. Ltd..

Document status and date:

Published: 01/01/1998

Document Version:

Publisher's PDF, also known as Version of record

\section{Please check the document version of this publication:}

- A submitted manuscript is the version of the article upon submission and before peer-review. There can be important differences between the submitted version and the official published version of record.

People interested in the research are advised to contact the author for the final version of the publication, or visit the DOI to the publisher's website.

- The final author version and the galley proof are versions of the publication after peer review.

- The final published version features the final layout of the paper including the volume, issue and page numbers.

Link to publication

\footnotetext{
General rights rights.

- You may freely distribute the URL identifying the publication in the public portal. please follow below link for the End User Agreement:

www.umlib.nl/taverne-license

Take down policy

If you believe that this document breaches copyright please contact us at:

repository@maastrichtuniversity.nl

providing details and we will investigate your claim.
}

Copyright and moral rights for the publications made accessible in the public portal are retained by the authors and/or other copyright owners and it is a condition of accessing publications that users recognise and abide by the legal requirements associated with these

- Users may download and print one copy of any publication from the public portal for the purpose of private study or research.

- You may not further distribute the material or use it for any profit-making activity or commercial gain

If the publication is distributed under the terms of Article $25 \mathrm{fa}$ of the Dutch Copyright Act, indicated by the "Taverne" license above, 


\title{
17 Proactive policing: limiting the role of the defence lawyer
}

\author{
ED CAPE AND TARU SPRONKEN
}

\section{Introduction}

Defence lawyers occupy a potentially ambiguous position in both of the major legal traditions in Europe. The principle of 'equality of arms', implicit in the European Convention on Human Rights (Gomien et al. 1996, p. 190196), gives rise to the explicit right of a person charged with an offence to the assistance of a lawyer (Article 6.3.c). This has been given a broad interpretation by the European Court of Human Rights, so that the right to legal assistance does not merely arise at the point at which a person is formally charged with a criminal offence but, it would seem, arises at the earlier stage of police interrogation prior to charge. ${ }^{1}$ However, whilst the right of access to a lawyer at the interrogation stage has come to be accepted as implicit in the European Convention, the proper role of the lawyer has yet to be explicated. Article 6.3.c refers to the right of a person 'to defend himself in person or through legal assistance', but the precise meaning of 'defend himself' is less than clear, and requires interpretation in the context of other provisions of Article 6 in particular. ${ }^{2}$ In any event, a more accurate picture of defence lawyers' actual, as opposed to theoretical, role may be gleaned from analysing the legal context within which lawyers work, and from research into the work that defence lawyers do.

This chapter examines the implications of proactive policing ${ }^{3}$ for defence lawyers, and defence lawyering, in the Netherlands and in England and Wales. It seeks to establish those issues that are jurisdiction-specific and, more importantly, those issues that cross jurisdictional boundaries. In circumstances where European states are increasingly seeking harmonization in approaches to policing and crime investigation, ${ }^{4}$ and in which proactive methods of police investigation are becoming more commonplace, ${ }^{5}$ it considers the effects of proactive police investigation on evidence gathering pre 
and post-charge, and on the use (or non-use) of evidence at trial, and also examines the implications of these developments for the role of defence lawyers.

Whilst there are important, and significant, differences between the legal context of defence lawyers' practice in the Netherlands and in England and Wales, which will be explored in this chapter, it is important to note that a common characteristic of both jurisdictions is that defence lawyers frequently have difficulty in securing access to information in the hands of the police at the investigative stage of the criminal process. This, it will be argued, is crucial in the context of proactive police investigations. Further, whilst the right of a suspect to access to a lawyer during police interrogation does, at present, differ significantly as between the two jurisdictions, the legal consequences of denial of access are not necessarily so divergent. ${ }^{6}$

For the defence lawyer a number of general problems may be identified as arising from, or in connection with, proactive police investigation.

1) Many forms of proactive police investigation are characterized by secrecy, frequently sanctioned by the courts. The involvement of an informer is normally not disclosed to a suspect/defendant; the location of a surveillance post is often kept secret; an undercover police officer may give anonymous evidence. Other problems flow from secrecy, in particular the often intractable problem of establishing relevance, necessary where seeking to persuade a court to order disclosure, or in seeking the exclusion of other evidence. ${ }^{7}$

2) Many forms of proactive investigation are largely unregulated by statute. In England and Wales, only the interception of public postal or telephonic communications is regulated by statute: the use of informers, undercover police, physical and electronic surveillance or bugging is not. ${ }^{8}$ This has significant implications for the reception of evidence obtained by such methods. In effect, neither the courts nor government takes responsibility for regulating such activity. ${ }^{9}$ In the Netherlands, investigative methods should have an explicit legal basis and police investigations should only take place in the manner laid down by law. ${ }^{10}$ However, in the context of the priority which in recent years has been given to countering serious and organized crime, new investigative methods which do not have a legal basis, such as infiltration, front-store operations, various forms of surveillance, and the gathering, registration and processing of data and information, have not been considered by the courts as unlawful. The courts have justified such practices by reference to the general duties of the police and judicial authorities as laid down in 
Article 2 (formerly 28) of the 1993 Police Act and Articles 141 and 142 of the Dutch Code of Criminal Procedure. ${ }^{11}$ Lack of legal accountability, when added to secrecy, is an explosive cocktail. The scandal that broke when it was discovered that tonnes of unlawful drugs had been imported into the Netherlands under the supervision of an Inter-regional Crime Squad and the Criminal Intelligence Unit of Kennemerland led to the establishment of the Parliamentary Inquiry conducted by the Van Traa commission. ${ }^{12}$ In its final report, the commission advised the Dutch Parliament that it should improve both the standards of competence of and the levels of responsibility for such police activities. The commission stressed that both the examining judge and the trial judge should actively control police investigations. This would require all investigative methods, and their results, to be made known at the trial. ${ }^{13}$ The government accepted most of these recommendations ${ }^{14}$ but whether effective regulation and control of investigative methods will be achieved will depend upon the precise form of the new legislation, and the attitude of the courts.

3) In England and Wales the police develop their own law-enforcement priorities for which they are scarcely accountable in a democratic sense. Determining investigative priorities reactively, by relying upon victim or witness reporting, it may be argued, provides only marginally greater accountability. However, when associated with secrecy, proactive policing means that priorities are left entirely to the police to develop and may, in some circumstances, depend upon illegitimate considerations. A person may be targeted, not because of the likelihood of their committing a crime, or because of the significance of crimes that they may be committing, but because they have been identified by an informer who has his or her own motives for placing the police spot-light on them (Cape 1996). Equally, an informer may be given 'permission' by the police to commit crimes. ${ }^{15}$ Illegitimate or questionable policing priorities, whilst usually not relevant to the construction of a defence, may be relevant to mitigation, if they could be established.

The general problems outlined above affect the position of the defence lawyer during both the pre-trial stage and the trial stage. Pre-trial the main concern is that of how to advise a client once arrested given the lack of access to information in the hands of the police. This is exacerbated in the Netherlands by the fact that defence lawyers can be, and normally are, denied access to their clients during police interrogation. At the trial stage problems centre on the opportunities for the defence to challenge evidence 
resulting from proactive police methods. The sanctioning of illegal (or unfair) police activities within the criminal trial, in respect of which the legal traditions of the Netherlands and England and Wales differ significantly in principle, has inevitable consequences for the role of defence lawyers at trial stage.

\section{The pre-trial stage}

One of the consequences of proactive police investigations, especially those involving the targeting of people suspected of being involved in crime, is that the police will frequently (although not always) have gathered most of the evidence they need for the purposes of prosecution prior to arrest. Indeed, one of the underlying purposes of proactive policing is to shift the emphasis away from interrogation and evidence of confession. ${ }^{16}$ Thus a 'front store' operation will normally have allowed the police to gather electronically recorded evidence of the identity of, and incriminating comments by, the suspect(s), fingerprint evidence, physical evidence of goods stolen, and evidence relating to the source of those goods. A simple undercover drugs operation involving delivery of drugs to a person suspected of dealing in drugs will result in tape-recorded evidence of delivery of a package to the suspect, and of any comments made on delivery, forensic evidence relating to the contents of the package, and possibly electronically recorded evidence of conversations involving the suspect prior to the delivery. Reasonable suspicion for the purpose of justifying an arrest ${ }^{17}$ will, therefore, have easily been established.

There are important differences between England and Wales, and the Netherlands, in relation to the position of the suspect and the powers of the police following an arrest. First, the police in England and Wales do not have the power to detain the suspect for interrogation where there is sufficient evidence to charge him or her, but must proceed to make a decision whether to charge. ${ }^{18}$ Once the suspect has been charged they may not, in normal circumstances, be questioned about the offence. ${ }^{19}$ This is not the case in the Netherlands, where the police are permitted to interrogate a suspect even when there is enough evidence to charge him or her. ${ }^{20}$

Second, a suspect in England and Wales who has been arrested and is detained at a police station has a well established right to legal advice (PACE section 58), which includes a right to have a lawyer present during any police interview (Code of Practice $C$ paragraph 6.8). In the Netherlands the issue of whether the lawyer has a right to be present during the police 
interrogation of their client is hotly disputed. ${ }^{21}$ The common practice of the police is to refuse to allow the lawyer to attend interrogations. ${ }^{22}$

Third, in England and Wales neither the defence lawyer nor the suspect has any right to information from the police at the pre-charge stage, other than the fact of and grounds for arrest (PACE section 28), the reason for detention (PACE section 37(5)), and whatever information is entered on the custody record (Code of Practice C paragraph 2.4). ${ }^{23}$ In the Netherlands the suspect and the defence lawyer have, even in the pre-trial stage, the right under Articles 30 and 51 of the Code of Criminal Procedure to all of the information which is included in the file. However, the public prosecutor is responsible for compilation of the file (which should include all relevant information obtained during the police investigation) and is likely to add to the file at this stage only the minimum information necessary to justify pretrial detention. In any event, during the pre-trial stage, information can be withheld temporarily from the defence in the interests of the investigation (Article 30 sub 2 CCP). The defence can ask the court to order the prosecutor to add all relevant information to the file (Article $31 \mathrm{CCP}$ ), but in the initial stage following arrest the courts often agree with the prosecutor that the information should be temporarily withheld from the defence. At the end of the preliminary investigation, and prior to the official charge, ${ }^{24}$ the prosecutor has to disclose all material in his or her possession. However, in practice relevant information may be withheld from the suspect at this stage without the defence or the court knowing of it. ${ }^{25}$ This is especially likely after a proactive police investigation because the police will frequently want to keep their investigative methods secret. The prosecutor may justify a decision to withhold information by stating that the specific information is not relevant to the question of establishing guilt or innocence, or that it should be kept secret in order not to prejudice future investigations in similar cases.

The crucial point, both in the Netherlands and England and Wales, is that if little or no information about the evidence in the hands of the police has been given to the lawyer, in practice he or she has no (lawful) mechanism for obtaining that information in the period immediately following arrest of the client. If some information is given by the police, the lawyer has no way of knowing whether the information given is complete or, indeed, accurate. In such circumstances, the lawyer may conclude that the safest course of action is for his or her client not to answer police questions. However, the lawyer cannot be sure that failure to answer questions will not ultimately work to the disadvantage of his or her client at a subsequent trial. ${ }^{26}$

In addition to the question of what, and how much, information may be 
obtained from the police, the question of what evidence the defence lawyer seeks from other sources also arises. Although this is relevant in any type of criminal investigation, it has particular significance with certain forms of proactive police investigation. Where the police have carried out physical surveillance in a city centre, or where a test purchase has been made, the lawyer may wish to discover whether any video cameras contain relevant footage. This may show, for example, that the surveillance record is inaccurate or it may provide alibi evidence. Where the lawyer and/or client suspect the involvement of an informer, which is not admitted by the police, the lawyer may wish to trace the person or at least secure information about him or her. Where the case involves forensic evidence, or other expert evidence, the lawyer may wish to instruct his or her own expert.

At the investigative stage, there are severe impediments in the way of the defence lawyer conducting any but the most rudimentary of investigations prior to interrogation and/or charge. The primary difficulty is that of time. Although the police investigation may have lasted for many months, once an arrest is made, a number of factors come into play. First, the police will be working to their own timescale and may not be willing to delay interrogation for this reason and because of legal constraints on the length of detention. ${ }^{27}$ The police do have power to grant bail to a suspect pending further enquiries (PACE section 37(2)), which would have the effect of suspending the detention time limit, but they are likely to be reluctant to do so where the alleged offence is serious. In the Netherlands, the exercise by the suspect of the right to silence will, in most cases, lead to a long period of pre-trial detention. Although bail is possible, it is rarely granted, and never in situations where there are still investigations to be carried out.

Second, defence lawyers do not have the authority of public office or the special powers available to the police to secure access to information or evidence in the hands of third parties. Therefore information or evidence that is outside the immediate possession or control of the client may prove impossible to secure. Third, with regard to physical evidence in the hands of the police, whilst it may be possible at some later stage to gain access to it in order, for example, for forensic examination and tests to be carried out, it would not be possible at this stage.

It may be concluded, therefore, that both in the Netherlands and the UK, the defence lawyer, prior to interrogation or charge, is almost entirely dependent upon the police or prosecutor for information and potential evidence. The police have a wide discretion to decide what information to disclose to the defence, and there is little the defence can do to extract from the police information which they are reluctant to disclose. It is in proactive 
investigation cases that the police are most reluctant to do so. Yet the suspect is at risk, in terms of the attitude of the court at any trial, if he or she decides (whether or not on legal advice) not to disclose information to the police. ${ }^{28}$ Indeed, the question might be asked, what is the lawyer for in such circumstances? Despite the endorsement of the right of access to legal advice by the European Court of Human Rights, in circumstances where there is no right to information from the police, the advantages of such access may be limited.

\section{The trial stage}

The proposition that fair trial requires fair pre-trial procedures is fundamental to a due process conception of criminal justice. It is clear that the difficulties of the defence so far considered have implications for the fairness of a subsequent trial. In particular, secrecy and lack of disclosure is a common thread throughout both phases. In this part we examine four issues arising out of proactive policing that are of particular concern to defence lawyers during the trial phase. It is worth noting before proceeding that inquisitorial theory implies that the defence, at trial, will have full knowledge of information gained during the investigation, if only as a by-product of the requirement that the court be appraised of all relevant information. Adversarial theory, on the other hand, enables each party, in principle, to decide what information to disclose to the other, both before and at trial, although in the interests of equality of arms, the prosecution is required to disclose certain information to the defence prior to trial. ${ }^{29}$

The first issue concerns the extent to which the trial provides the defence with the opportunity to effectively challenge irregular or unlawful methods of investigation used by the police in the pre-trial phase. This is, of course, closely related to the question of whether the trial process, besides being a legal construction to establish guilt or innocence by a fair procedure, ${ }^{30}$ is also a mechanism for controlling police conduct during the criminal investigation. The second issue concerns the problems for the defence in finding out about any proactive police inquiries that may have been made, and information thus obtained, before the criminal offence occurred or a reasonable suspicion of the defendant arose, which the prosecution may not wish to use or reveal at trial. The third issue concerns the regulatory mechanisms within the criminal trial which preserve the secrecy of proactive investigative methods where such methods produce evidence which can be, and is, presented at trial. One of the primary threats to fair trial is the inherent 
secrecy of most proactive methods, with the consequence that the resulting evidence cannot be effectively challenged by the defence. The fourth issue is the way in which the European Convention on Human Rights, especially in respect of the procedural guarantees of fair trial (Article 6) and the guarantees protecting privacy (Article 8), can be invoked by the defence in the criminal trial.

\section{Criminal procedure as means of controlling the police}

In continental inquisitorial systems the regulation of official action and hierarchical review are basic components of the criminal process (Damaška 1986). In the Netherlands all police activities should be hierarchically supervised, and regulated and monitored by trial judges. This derives from the principle of legality which is laid down in Article 1 of the Code of Criminal Procedure that criminal proceedings must be conducted as provided by law. Articles 140-148 CCP make the prosecutor responsible for criminal investigations by the police, and Articles 152-153 CCP provide that investigating police officers must record all of their activities in official reports which must be added to the file in order to give the judge the opportunity to check whether the prosecution has acted in a lawful way and has had regard to the principles of due process. ${ }^{31}$

The principle that there should be an internally consistent network of rules by which the police, and criminal investigations, are regulated and supervised by the courts, demands that police officers, when requested by the court, must make clear what decisions they have taken and why. This in turn gives the defence an opportunity to play its part in the control of police activities through its participation at trial. The result is that the defence in the Netherlands is not restricted to defending an accused in the classical sense of challenging the inculpatory evidence and putting forward information which could lead to an acquittal or less severe punishment. Besides the defence lawyer's duty to protect the civil rights of defendants, which is seen as part of the common interest in protecting civil rights in general (Corstens 1995, pp. 88-89; De Roos 1991, pp. 14-17), monitoring police and prosecution actions in the pre-trial stage is also useful as a specific defence strategy because unlawful investigation methods may lead a court to order that a trial should not proceed at all, or to decide to exclude the evidence so obtained. As a result the defence lawyer regards it as part of his or her professional duty to check whether the investigating officers - especially during a period of proactive investigation - have exceeded their authority or have breached 
the rules regarding search, seizure and other investigative methods which, in principle, are regulated by law.

In the adversarial system of England and Wales, where police investigative methods are largely unregulated by statute, the use of proactive methods is lawful unless they involve an activity that is prohibited by the general criminal law. ${ }^{32}$ This is the converse of the position in the Netherlands. The traditional common law attitude is that the court's primary concern is that of relevance; it is not for the courts to control police activity. Therefore, not only have the police historically enjoyed freedom of action in the sense that most forms of investigative activity have not been regulated by law and thus the question of illegality does not arise, but even where police investigations have breached the criminal law the courts have taken the view that it is not their concern. As Crompton J. said in the oft-quoted case, $R v$ Leathem, 'It matters not how you get it: if you steal it even, it would be admissible in evidence ${ }^{33}$ However, this stark approach was qualified, even at common law, so that courts have the power to exclude evidence if its probative force is outweighed by its prejudicial value ${ }^{34}$ and an exception has been made in relation to evidence of confession. ${ }^{35}$

The traditional approach must now be seen in the context of a number of statutory and common law developments over the past decade. First, section 76 of PACE provided that evidence of confession by the defendant is not admissible unless (where it is raised by the defence) the prosecution can prove that it was not obtained by oppression or in circumstances likely to render it unreliable. Of more particular relevance to proactive policing is section $78 \mathrm{PACE}$ which grants a discretion to a court to exclude prosecution evidence on the grounds of fairness. ${ }^{36}$ In making this decision, the court must have regard to all the circumstances, including the circumstances in which the evidence was obtained. Thus under section 78 a court should not primarily be concerned with issues of illegality, but rather with questions of fairness, which may or may not involve considerations of illegality. This is of particular importance where, as noted above, there is minimal legal regulation of police investigation, so that issues which may in other jurisdictions be issues of legality have to be approached, in England and Wales, by way of the elusive concept of fairness. However, in most cases involving evidence derived from proactive police investigation, the Court of Appeal and the House of Lords have endorsed the view that such evidence, even if involving illegality on the part of the police, should be admitted. ${ }^{37}$ Thus in $R v$ Khan (Sultan) ${ }^{38}$ the House of Lords held that evidence from an electronic listening device placed on a third party's house unlawfully (since it involved civil trespass and possibly criminal damage), but in accordance 


\section{Ed Cape and Taru Spronken}

with Home Office guidelines ${ }^{39}$ was admissible. ${ }^{40}$ It further held that the judge was entitled to exercise his or her discretion under section 78 not to exclude it even if there had been illegality and even if there was a breach of the right to privacy under Article 8 of the European Convention on Human Rights. Since most proactive police activity is unregulated by law, the question of illegality ${ }^{41}$ will not normally arise, the only question for the court being one of faimess of the proceedings. Thus activities which might be unlawful in other jurisdictions, such as the bugging of private conversations (at least without some form of judicial authority), are not illegal and in most cases where the issue has arisen, the courts have not regarded it as adversely affecting the faimess of the proceedings and have, therefore, admitted the evidence. ${ }^{42}$

A further area of development is that in relation to abuse of process, whereby the court is entitled to refuse to allow a prosecution to proceed where to do so would amount to an abuse of the criminal process by reason of oppression or vexatiousness. ${ }^{43}$ Whilst this has been used to deal with situations where there has been undue delay in bringing criminal proceedings, it has also been argued by the defence that it should apply where the prosecution have acted unlawfully. For example, in $R v$ Latif; $R v$ Shah$\mathrm{zad}^{44}$ the defence argued that the prosecution should be stayed where the defendants had been lured to England by means of a trick to receive drugs unlawfully imported by a Customs and Excise officer. However, the House of Lords held that the trial judge was correct, having considered the conflicting considerations of policy and justice, in concluding that there was no abuse of process. ${ }^{45}$

In principle defence lawyers in both jurisdictions must act in the best interests of their clients, which requires them to prepare the most favourable case possible to present to the court. ${ }^{46}$ However, unlike their Dutch counterparts, the professional duty of English and Welsh lawyers does not extend to examining the lawfulness of police conduct as such. The English and Welsh lawyer is most definitely not a party to a process of regulating and supervising the police, a role that has, in any case, been largely eschewed by the courts. The concern of the defence lawyer in England and Wales in relation to proactive police investigation is more limited, being confined to the question of whether any police activity in relation to the investigation may find an argument for the exclusion of evidence or, very exceptionally, may enable the lawyer to argue abuse of process. ${ }^{47}$ In circumstances where proactive policing is largely unregulated so that most police activity is regarded as lawful, and where the courts are likely to admit evidence obtained by proactive methods even if it has been unlawfully or unfairly 
obtained, ${ }^{48}$ the limits of the role of the defence lawyer in this regard are inevitably severely circumscribed. Even if they do examine the legality of police action, and even if they do discover some unlawful police activity, in most circumstances this is unlikely to benefit their client at trial. ${ }^{49}$

\section{Knowledge of proactive activities}

One of the main characteristics of cases involving proactive policing is that the suspect is arrested after the criminal investigation by the police is completed, often caught (apparently) in the act of committing a crime. The arrest is often preceded by long periods of police surveillance, involving a combination of physical and electronic surveillance, telephone tapping, undercover agents, informants or infiltrators. In this context it is important to realise that the line between proactive and reactive policing is rather fluid, and that secretive investigative methods used in the proactive phase such as observation, surveillance and the use of undercover agents or informants, can also be employed in a reactive way. Following arrest the suspect may be confronted with the evidence gathered during the proactive phase of the investigation, although only in so far as the information is likely to be used at trial. ${ }^{50}$ However, once caught in the act, there is normally enough evidence to establish guilt at trial without reference to information gathered at the earlier stage, and without reference to the methodologies involved.

The information gathered during the proactive phase, and the methods used in order to gather it, may be important from the defence point of view. It may demonstrate that the police or other investigative agency has acted illegally or unfairly, either because it involved the commission of an offence, or because the police have exceeded their powers. ${ }^{5 \mathrm{I}}$ Alternatively, the information may undermine the prosecution evidence that is to be put before the court, or may assist the defence, either by supporting a defence to be put forward or by pointing to another defence not considered. Further, it may include information that may be of assistance to the defence in terms of mitigation, by casting the involvement of the defendant in a different light, perhaps by establishing entrapment or other forms of reduced culpability.

In the Netherlands, proactive methods which have led to such evidence are frequently kept out of the file and thus kept secret from the defendant and his or her lawyer, and also from the trial judge. The initial police record in the dossier usually starts with the announcement that, for instance, the police received information from criminal intelligence sources that at a certain place a drug deal would be made or that in a certain building drugs 
would be stored. Thus prior to a telephone tapping or surveillance operation the police record may simply state that the subjects of the operation were identified as taking part in a criminal organization. The source of this information is, however, kept secret. According to regular jurisprudence of the Dutch courts the prosecutor is not obliged to disclose the source of such information unless the defence can plausibly argue that the information was gathered in an illegal way or that the information would give the judge serious grounds to suspect that evidence had been gathered illegally. ${ }^{52}$ This is, of course, difficult without knowledge of what was going on in the proactive phase. Thus it is often only by accident that the defence discovers that there has been proactive investigation prior to arrest.

In England and Wales, in the absence of an obligation to present all relevant information to the court of trial, the question is whether the prosecution must disclose information relating to or resulting from proactive investigative methods. This involves a two stage process. The prosecution must first decide what evidence it wishes to present to the court of trial in order to seek to establish guilt. Although under a general obligation to act fairly, ${ }^{33}$ it is not under an obligation to present evidence that undermines the prosecution or assists the defence. The second stage involves the prosecution in deciding, from the information in its possession that it does not intend to use as evidence, what to disclose to the defence in advance of trial. This has been the subject of rapid jurisprudential development in the past few years. Broadly, the prosecution are under an obligation to disclose information to the defence if it is relevant or possibly relevant to an issue in the case, or raises or possibly raises a new issue that it is not apparent from the evidence that the prosecution intends to use at trial, or which holds out a real prospect of providing a lead on evidence that goes to the former. ${ }^{54}$ The purpose is to enable the defence to pursue its own enquiries and to use it as a basis for conducting its own defence at trial. This obligation, of course, entails placing trust in the integrity of both the police and the prosecution since it is only enforceable by the defence if information comes to light that the prosecution has an interest in suppressing.

Even if the trust is justified in most cases, the obligation to disclose is circumscribed by the ability of the prosecution, with the sanction of the court, to withhold relevant information from the defence on the grounds of public interest immunity (PII). Although in some circumstances the prosecution must at least inform the defence of the category of information that they hold, in certain circumstances, the prosecution can withhold even this information. ${ }^{55}$ It is well established that most police communications are covered by public interest immunity, ${ }^{56}$ as is (normally) information relating 
to informers and methods of detection such as the identity of a police observation post. The judge, in considering a PII application is, however, under an obligation to balance the competing interests of preserving the integrity of police investigation and fairness to the accused. Thus the judge should not uphold a PII application where disclosure is necessary in order to establish innocence or to avoid a miscarriage of justice, such as where the informer was a participant. What may help to establish innocence, of course, depends in part upon what is regarded as a sufficient reason to exclude evidence. Since proactive policing is largely unregulated, and since even illegal police actions do not necessarily lead to the exclusion of evidence, it will be difficult to persuade a judge that such information, withheld by the prosecution, is necessary to help establish innocence. ${ }^{57}$ Further, as in the Netherlands, if the defence are not aware of what was done by way of proactive policing, it will frequently be difficult if not impossible for them to challenge an application by the prosecution for information to be witheld, a situation exacerbated, of course, if the defence are not even aware of an application to the court. Securing such information may thus depend upon accidental discovery, or on a particularly proactive and persistent defence lawyer.

The problems, and differences in approach between the two jurisdictions are perhaps best illustrated by an example from the Netherlands. In a drugs case, which was dealt with by the Utrecht District Court and the Amsterdam Court of Appeal, ${ }^{58}$ the file included several police reports of observations of a shed where drugs were hidden made shortly before arrest, with detailed information about the visitors to the shed and the activities in the shed. At the trial it became clear that the police officers had not been at the scene (as the written records purported to show), but that the observations had been made by a video-camera positioned outside the shed. The police officers who drew up the records were requested by the court to rectify them. In the meantime a feature was published in the newspapers suggesting that the police had broken into the shed and placed a video-camera inside (the press is often better informed than the courts and the defence!). The defence requested that the police officers be questioned in court. It was important to know when the video-camera had been installed, and whether the police had authority to enter the building in order to install the camera, and whether there was reasonable suspicion of a crime at the time that the camera had been installed. ${ }^{59}$ The defence also made a request to see the video-tapes, which would demonstrate whether the police officers, who had denied illegally entering the shed during an earlier court session, were telling the truth. It transpired that the videotape had been destroyed, and thus the court 
stayed the prosecution. It did so on the grounds that it had been wilfully misled by the police and prosecutor - covering up the source of their observations by leaving out of the records the fact that the observations were made by video - and thus giving false information to the court, and by doing so, destroying the evidence (i.e. the video-tapes) necessary for control of the police.

There have been several cases like this, in which important information has been deliberately kept out of the file or where police records were incomplete or contained false information about the source of the information in order to keep the methods and sources secret. In those cases where the information was subsequently given to the court following a request, the courts have decided that the prosecution was admissible (that is, should not be struck out) and the evidence was not excluded. ${ }^{60}$ However, in those cases where the courts were left with the impression that the prosecution had frustrated judicial control by withholding information during the trial, evidence was excluded or the prosecution was not permitted to proceed. ${ }^{61}$

How might a court in England and Wales deal with such a case? Assuming that the video film is favourable to the prosecution, since the courts are concerned primarily with factual relevance rather than legality the police and prosecution would almost certainly disclose the video tapes to the defence, and use them as evidence, without risk of exclusion. ${ }^{62}$ The defence, having had disclosure, might seek to persuade a court to exclude such evidence on the grounds of unfairness, or might even seek to stop the trial on the ground of abuse of process, but would be highly unlikely to succeed in either tactic. Suppose, however, that the video-camera had been secretly attached to a house opposite the shed. This may have involved illegality on the part of the police officers concemed ${ }^{63}$ but, as argued earlier, this is unlikely to act as an impediment to using the evidence so obtained. The primary issue, therefore, would not be whether the video film itself should be disclosed and used as evidence, but whether the location of the video camera should be disclosed. Provided certain guidelines had been followed by the police, it is unlikely that a judge would order the prosecution to disclose the location of the camera, particularly if the occupier of the house feared harrassment as a result of the disclosure. ${ }^{64}$

If the video, in the opinion of the prosecution, tended to undermine the prosecution or assist the defence, they would be under an obligation to disclose the video-tape to the defence prior to trial, although again, not the location of the camera. ${ }^{65}$ If the tape would inevitably disclose the location of the camera the prosecution could apply to the court for an order that the tape be withheld on the grounds of PII. The judge would then have to decide 
whether the prosecution should disclose the tape to the defence in the interests of a fair trial, which would require the judge to decide whether, and to what extent, it undermined the prosecution case or assisted the defence case, but in the absence of detailed knowledge of what the defence case was likely to be.

If the prosecution decided the video-tape was not relevant on the Keane criteria ${ }^{66}$ they need not disclose it, either to the defence or to the court. If the defence knew of its existence, it could ask, and if necessary apply to the court, for it to be disclosed. The court would then decide on relevance according to the Keane criteria, subject to any PII claim by the prosecution. $^{67}$

During and after the Dutch parliamentary inquiry of the Van Traa commission into the use of proactive methods, the question of the extent of the prosecution's obligation to add information to the file became an issue, frequently raised in trials. In general the prosecutor is obliged to add to the file all the material evidence for or against the accused. ${ }^{68}$ The primary question is whether the prosecution can be effectively obliged to disclose information which in itself is not of direct evidential value, but which may be of importance to establish the (un)lawfulness of the evidence. The District Court of Rotterdam has ruled that all information which could be relevant to the case should be regarded as a record in accordance with Article 30 CCP and must be added to the file. ${ }^{69}$ According to the Van Traa commission, all investigative actions, both in terms of relevant information and the methods used to obtain the information, should be reported in the written record, ${ }^{70}$ and added to the file, so that it is made known to the judge and defence. However, the commission recommended that when third parties could be threatened, or the public interest could be severely damaged, as a result of the disclosure of such information, the prosecutor should be able to seek permission of the investigating magistrate to withhold the information from the file. If the investigating magistrate refuses to give permission the prosecutor could either add the information to the file or drop the charges. If the examining magistrate gives permission to withhold the information, the defence should be informed that the file is not complete. ${ }^{71}$ Until now it has only been at the request of the defence that the courts have ordered the prosecution to disclose information which is relevant to the lawfulness of the evidence. It can hardly be expected that the prosecution will give this kind of information voluntarily, especially when investigative methods will only be effective when they are kept secret. So the dilemma remains. Should the defence be given a full opportunity to control policeactivities or should there be exceptions, as suggested by the Van Traa 
commission, leaving it to the judiciary to decide whether certain information can be kept secret?

In England and Wales, the political impetus toward secrecy has been greater than that reflected by the recommendations of the Van Traa commission's report. The Criminal Procedure and Investigations Act $1996^{72}$ reduces the obligation on the prosecution to disclose unused material, whilst requiring the defence, for the first time, ${ }^{73}$ to disclose its defence in advance of trial. Whilst the Act does not directly affect the question of what may be withheld on the grounds of public interest immunity, it does make the prosecution's duty to disclose material which may be of assistance to the defence $^{74}$ conditional on the defendant disclosing to the prosecution a defence that shows such information to be relevant. To the extent that the police or prosecution do not wish to disclose material arising from proactive policing, the 1996 Act is likely to make it easier for them to do so.

\section{Anonymous testimony}

The previous section was primarily concerned with the question of whether proactive investigation methods, or the product of such methods, should be disclosed to the defence and to the court. We now focus more particularly on the trial process itself and examine the specific issue of anonymous testimony. This concerns, of course, evidence that is put before the court by the prosecution, but in respect of which the prosecution seeks to withhold the identity of the evidence giver, whether or not that person is in court to give their evidence. In the Netherlands the admission of hearsay evidence has opened the way to admitting anonymous written statements as evidence, since once the decision was taken to allow hearsay evidence, there was no legal obstacle to prevent the original source of the evidence from remaining undisclosed. ${ }^{75}$ The admission of anonymous testimony has facilitated the use of evidence gathered by proactive policing because in this way statements of informers, infiltrators and undercover police officers can be used as evidence at trial whilst preserving their anonymity and reducing the opportunity for the defence to challenge and question such witnesses. After the Kostovski case ${ }^{76}$ the use of anonymous testimony as evidence in the Netherlands, which until then had no legal basis, has been regulated by law (Articles 226a-226f CCP, which came into force in February 1994). According to this law anonymity is permitted to threatened witnesses, provided that there is corroborating evidence from a non-anonymous source, ${ }^{77}$ and provided that the defendant has had the opportunity to question the witness at 
some stage (although such questioning can be severely limited by the investigating judge, for example by only permitting written questions). It is still uncertain whether this new regulation is compatible with the requirements of Article 6 of the European Convention. The primary issue is to what extent the rights of the defence to challenge the evidence can be restricted without violating the principles of a fair trial.

Jurisprudence of the European Court requires that normally all evidence must be produced in the presence of the accused at a public hearing with a view to adversarial argument. In certain cases the use of statements obtained in the pre-trial stage is not regarded, in itself, as inconsistent with the paragraphs 3.d and 1 of Article 6, provided that the rights of the defence to question and challenge the witness have been respected. ${ }^{78}$ In a recent judgement in the Doorson case ${ }^{79}$ the European Court ruled that the Convention does not preclude reliance, at the investigation stage, on sources such as anonymous informants, but that the subsequent use of such statements by the trial court to found a conviction is capable of raising issues under the Convention. In the Doorson case, because the anonymous witnesses were questioned by an investigating judge in the presence of Doorson's lawyer, who could ask whatever questions he considered to be in the interest of the defence as long as they would not lead to disclosure of the identity of the witness, and since these questions were all answered, the Court was of the opinion that the 'counterbalancing' procedures followed by the judicial authorities were sufficient to have enabled the defence to challenge the anonymous witnesses. Nevertheless the Court considered that even when 'counterbalancing' procedures are found to compensate sufficiently the handicaps under which the defence labours, a conviction should not be based solely, or to a decisive extent, on anonymous statements. In a judgement of 23 April 1997 in the case of Van Mechelen and Others $v$ Netherlands, the European Court set out the conditions on which anonymous testimony is admissible.$^{80}$ In its report on this case, the European Commission was of the opinion ( 20 votes to 8 ) that although the convictions were based to a decisive extent on anonymous statements of police officers Article 6.3.d was not violated because the accused and their lawyers were able to put questions by telephone while the anonymous witnesses were questioned by the investigating judge. The European Court, however, was of a different opinion. According to the Court there had been a violation of Article 6.1 taken together with Article 6.3.d, inter alia because these measures could not be considered a proper substitute for the defence being able to question the witnesses in its presence and to make its own judgment as to their demeanour and reliability. 
In the adversarial procedure of the United Kingdom the principle of orality requires that, in general, facts may only be admitted in evidence if they are attested to in court by a witness who perceived those facts. This is reflected by the rule against hearsay. The principle of public justice requires that this process should be carried out in open court. As Lord Diplock stated in Attorney-General $v$ Leveller Magazine Ltd., "As a general rule the English system of administering justice does require that it be done in public ... in criminal cases at any rate, all evidence communicated to the court is communicated publicly.' This presents particular difficulty for the prosecution where they wish to use evidence that has resulted from proactive policing, ${ }^{82}$ since the general principles require that the evidence be presented in a public forum by the percipient witness. There are, however, two mechanisms which may assist the prosecution but, arguably, at the expense of the defence.

The first is provided by sections 23 and 24 of the Criminal Justice Act 1988, which enable first-hand hearsay (in the case of section 23) or first or second hand hearsay (in the case of section 24) to be admitted in evidence at trial in the absence of the witness. In particular, a written statement made by a prosecution witness may be used at trial without the need for the witness to attend provided the prosecution can establish, inter alia, that the witness 'does not give oral evidence through fear or because he is kept out of the way'. In principle this could be used where the witness is, for example, an informer, and even if the evidence forms the major part of the prosecution case. Although such evidence could only be admitted if the court was satisfied that it was in the interests of justice to do so (section 26), and it is less likely to be satisfied where the written evidence does form the major part of the prosecution case, there is no rule that it could not be used in such circumstances. ${ }^{83}$

The second mechanism is by providing for anonymity of a witness who does give oral evidence. This may involve the simple expedient of not requiring them to reveal their identity, ${ }^{84}$ or by permitting them to give evidence from behind screens so that they cannot be seen by the defendant or the public ${ }^{85}$ In the past, this has been used to protect the victims of rape and blackmail, and also child witnesses. ${ }^{86}$ In $R v$ Watford Magistrates' Court ex $p$ Lenman $^{87}$ it was used to conceal the identity of witnesses in a case of alleged gang violence, the rationale being that a judge had a duty to see that justice was done. If a judge is satisfied that there is a real risk to the administration of justice because a witness reasonably fears for his or her safety if his or her identity were to become known, the judge has a discretion to take steps to protect the witness and to reassure them so that they would not be deterred from coming forward. However, there is evidence that 
anonymity is increasingly, if not routinely, being granted to protect the identity of informers or undercover officers (Enright 1996). This is despite the Court of Appeal stating in $R v$ Taylor $^{88}$ that anonymity should rarely be allowed, and only where there are real grounds to fear the consequences of disclosure and that the evidence must be of sufficient importance to make it unfair to insist on the prosecution proceeding without it.

The problem is that the more important the evidence, the more likely that the defendant will be prejudiced by not knowing the identity of the witness. This is particularly so where the witness is an informer or undercover officer and where, for example, the defendant would wish to show that he or she has been entrapped into committing an offence that s/he would not otherwise have committed, or where the degree of culpability is in issue. In the Netherlands, this is partially alleviated by the requirement that there be corroborative evidence from another source, a requirement that is absent in England and Wales. But in both jurisdictions, the defence may be limited to asking questions (directly, or indirectly in the Netherlands) of a witness whose identity, and therefore credibility, is hidden from the defence and from the court. There is also the problem in England and Wales, as Enright (1996) notes, that "the mere fact that an officer gives evidence from behind a screen plants the seed of prejudice in the minds of the jury'. The Court of Appeal in the Taylor case held that anonymity should only be permitted if no undue prejudice is caused to the accused, but this indicates that the court is willing to permit some prejudice (provided that it does not amount to undue prejudice), and since research into juries is severely limited, ${ }^{89}$ a judge cannot be sure, in that particular case or in general, that any warning to the jury not to allow the fact of anonymous testimony to affect their judgement, is effective. Again as Enright notes, the options for the defence in such cases are limited.

\section{The European Convention on Human Rights}

The European Convention on Human Rights has provided a powerful and effective mechanism for the defence in the Netherlands to challenge the secrecy which surrounds proactive policing. As noted earlier, the European Court has taken a critical approach to the admissibility of anonymous evidence in relation to the concept of fair trial, and also to the implications for fair trial of the right to privacy as laid down in Article 8 of the Convention. ${ }^{90}$ In the Netherlands the application of national law can, and must, be set aside by the judiciary when it infringes the rights guaranteed by the Convention. As a consequence Strasbourg case law has become an important 
source of law that the defence can rely upon. Since the European Court sees it as its task to ascertain whether the proceedings, considered as a whole, are fair as required by Article 6 of the Convention, and since it has stated that the guarantees of Article 6 also apply at the preliminary stages of investigation into an offence by the police, ${ }^{91}$ the Convention offers to the defence the opportunity to challenge secretive investigation methods that threaten fair trial or private life as guaranteed in Articles 6 and 8 of the Convention.

The United Kingdom, however, has not incorporated the European Convention into domestic law. Although the government is obliged to take the Convention and the decisions of the European Court into account, it normally takes a minimalist approach, particularly to the latter (Klug et al. 1996, p. 133). The courts, generally, do not see themselves as a suitable forum for adjudication of human rights issues. ${ }^{92}$ Use of the Convention, and of decisions by the European Court, is therefore limited. It might be cited by the defence where it is seeking to persuade a court that legislation should be construed in accordance with the Convention, ${ }^{93}$ but it was confirmed in $R v$ Secretary of State for the Home Department ex $p$ Brind ${ }^{94}$ that this is really only relevant where the court is required to construe any provision that is 'ambiguous in the sense that it is capable of a meaning which either conforms to or conflicts with the Convention'.$^{95}$ In any event, since most forms of proactive policing are not governed by statute, this form of appeal to the Convention is not normally available.

The defence may argue that evidence obtained by proactive means was secured in contravention of the Convention. However, even if a court accepts that this was the case, it will not necessarily lead to exclusion of the evidence since the basis for exclusion of evidence is fairness rather than illegality. In $R \vee \mathrm{Khan}^{96}$ the defence argued that in deciding whether evidence from an unlawfully placed listening device should be excluded the court should have regard to the Convention and decisions of the European Court. The House of Lords commented that ' $[t]$ he principles reflected in the Convention could hardly be irrelevant to the exercise of the 578 power because they embodied so many of the familiar principles of English law and concept of justice.' However, it went on to hold that since unlawfulness per se was not a reason for excluding evidence, ' $[t]$ he fact that the behaviour constituted a breach of the Convention ... could plainly be of no greater significance per se than if it constituted a breach of English law.' Clearly this area of law is developing, but even if the Convention were to be incorporated into English law, its usefulness to the defence will be limited for as long as substantive faimess răther than legality remains the guiding principle for the admission of evidence. 


\section{Conclusions}

Proactive policing raises in an acute form a number of problems that defendants and defence lawyers experience in both inquisitorial and adversarial systems. It emphasizes the inequalities of power and resources as between the suspect or defendant and the state, whether the suspect/defendant is an object of an inquisitorial investigation or a party to an adversarial process. Under both systems, the police have strong inquisitorial powers and under both the defence lack an effective right to information held by the police, particularly at the investigative stage. At the same time, although the legal systems of the Netherlands, and England and Wales, approach the regulation of police powers in quite different ways, recent experience in the Netherlands has demonstrated that regulatory and supervisory mechanisms characteristic of inquisitorial systems do not necessarily prevent the police from engaging in forms of investigative policing which, although they may be lawful in England and Wales, nevertheless have an adverse effect on the faimess of the trial process.

We have identified one of the major characteristics of proactive policing as being that of secrecy. Secrecy is not a necessary corollary of proactive policing. In England and Wales, given the lack of regulation of investigative methods and the attitude of the courts, the prosecution are often under no particular pressure to withhold information from the defence. However, proactive policing is frequently accompanied by secrecy on the part of the police and prosecution, to protect informers and undercover agents from threat and/or discovery, to protect investigative methodologies, and sometimes to protect against the discovery of police activities that are on the margins of legality.

To the extent that secrecy can be justified, there is a clear need for political, organizational and institutional safeguards. Quite apart from the interests of fair trial, such mechanisms are necessary to ensure democratic accountability of the police, and to prevent a culture of corruption that is likely to develop from a sense of being above the law. ${ }^{97}$ That need is all the greater given the likely further development of proactive policing methods in response to the perceived threat of organized and cross-border crime, the political need to be seen to do something about rising crime levels ${ }^{98}$ and, as important, developments in available technology. However, it is the impact of secrecy on the possibilities for a fair trial process that is of most concern to defence lawyers, a process that is arguably under threat as a result of the elevation of the public interest in securing convictions, that 
currently finds public and political favour, above the public interest of fair trial.

It is in this context that regulatory mechanisms in both countries are inadequate. There are two ways in which this is so. First, the law in both jurisdictions facilitates an increasing degree of secrecy, allowing a variety of justifications for withholding information from the defence. Secondly, in so far as the law does not permit the police or prosecution to withhold information, existing mechanisms, whether administrative or judicial, fail to ensure compliance with the law. In both England and Wales, and in the Netherlands, it is ultimately left to the courts to decide what information should be disclosed to the defence. This requires a judge to take into account the interests of the defence without full knowledge of what those interests might be, and often in circumstances where the ability of the defence to argue for disclosure is hampered by the very secrecy which the defence is seeking to expose. Either the defence does not know of the existence of the evidence or it does not have sufficient knowledge of it to persuade the court that it should be disclosed.

The danger in both jurisdictions is that it is increasingly the police who not only decide which members of the population will be targeted for investigation but who, by the selective use and concealment of information, determine who shall be found guilty. In circumstances where secrecy is accompanied by an absence of effective mechanisms to ensure democratic accountability and by a failure of both political and legal institutions to take responsibility, proactive policing presents a danger not only to defendants, but to society as a whole.

\section{Notes}

1 In Murray v United Kingdom (Case No 41/1994/488/570) (1996) The Times, 9 February, the Court held that denial of access to a lawyer during police interrogation, in circumstances where the rights of the defendant might be irretrievably prejudiced, is incompatible with Article 6. The implications for member states of this decision have yet to be fully understood, for it would seem to follow that states must not only introduce (where they do not already exist) provision for legal advice for suspects whilst detained by the police, but must also create provision for the legal advice to be given free of charge where it is in the interests of justice to do so. Note that Principle 7 of the Basic Principles on the Roles of Lawyers, adopted by the Eighth United Nations Congress on the Prevention of Crime and the Treatment of Offenders in Havana, Cuba, on 7 September 1990, provides, somewhat ambiguously, that governments should 
ensure that 'persons arrested or detained, with or without criminal charge, shall have prompt access to a lawyer, and in any case not later than 48 hours from the time of arrest or detention'. For the Netherlands see Spronken 1996.

2 The Basic Principles on the Role of Lawyers (see note 1) does set out the duties of defence lawyers (Principles 12-15), but does not cover most of the important questions relating to the role of lawyers being discussed here. This is also true for the Netherlands, where the Code of Conduct (Gedragsregels 1992) contains few specific rules for lawyers in criminal cases.

3 The definition of proactive policing adopted in this chapter is that set out in the introduction.

4 See, for example, the Europol Convention signed by the European Union governments on 26 July 1995.

5 Encouraged in England and Wales by the influential Audit Commission report published in 1993, Helping with Enquiries: Tackling Crime Effectively, London: HMSO.

6 In the Netherlands, although a matter of dispute, lawyers do not have a right to be present during the police interview of suspects, and access to clients can be delayed for as long as the interrogation lasts. See for example HR 23 May 1995, DD 95.352 and District Court 's-Hertogenbosch 1 September 1995, NJ 1996, 29. In England and Wales, courts have not necessarily excluded evidence, even where the statutory right to legal advice has been deliberately denied. The mechanism for exclusion is primarily section 78 of the Police and Criminal Evidence Act 1984 (PACE), which requires the court to consider the effect of denial on the fairness of the proceedings. See, for example, $R v$ Alladice (1988) $87 \mathrm{Cr}$ App R 380, $R v$ Walsh [1989] Crim LR 822, $R$ v Dunford [1991] Crim LR 370 and $R v$ Anderson [1993] Crim LR 447, and contrast $R v$ Samuel [1988] QB 615 .

7 For England and Wales, see the Commentary to $R v$ Smith (Brian) [1995] Crim LR 658, at p. 660. For the Netherlands see Prakken 1995; Corstens 1995, pp. 228-229.

8 See the Interception of Communications Act 1985. The Police Act 1997, which received royal assent in March 1997, gives the police statutory authority to enter premises and plant bugging devices (although these provisions have not yet been implemented). Similar methods, when used by the security services, are governed by the Intelligence Services Act 1994. The security services were given a criminal investigation role, ostensibly confined to serious crime, by the Security Service Act 1996.

9 For a similar view in the context of the USA, see Marx 1988, esp. p. 48 and 50.

10 Article 1 Dutch Code of Criminal Procedure; Simmelink 1987; Knigge 1990; Naeyé 1995.

11 HR 14 October 1986, NJ 1987, 564; HR 14 October 1986, NJ 1988, 511; HR 8 July 1992, NJ 1993, 29 and HR 19 December 1995, Zwolsman, NJ 1996, 249.

12 Named after the Chairman of the commission. 


\section{Ed Cape and Taru Spronken}

13 Inzake opsporing 1996. However, the commission did suggest that there should be certain exceptions to the principle of full disclosure.

14 (Voorlopig) Regeringsstandpunt Enquête Opsporingsmethoden, TK 1995-1996, 24072 , nr. 26.

15 For a report of recent research, see Dunningham and Norris 1996.

16 In fact, the aim may not be prosecution at all but, for example, the dismantling of a criminal group or organization. Alternatively, proactive investigation may be directed at inflicting economic or fiscal sanctions outside of the criminal process. Nevertheless the Van Traa commission was of the opinion that the aim of exercising powers in relation to criminal offences should always be the imposition of a penal sanction.

17 Generally required for the exercise of powers of arrest. For England and Wales see PACE section 24, and for the Netherlands see Articles 57, 63, 67 and 67a $\mathrm{CCP}$.

18 PACE section 37 , although evidence suggests that this is routinely ignored by the police. See McKenzie, Morgan and Reiner 1990 and Bottomley, Coleman, Dixon, Gill and Wall, 1991, esp. p. 88.

19 PACE section 37, and Code of Practice C paragraph 16.5. The PACE Codes of Practice are a form of quasi-legislation issued by the Home Secretary under the authority of PACE section 66.

20 According to Articles 67 and $67 \mathrm{a} C \mathrm{CP}$, pre-trial detention is allowed in serious cases (most crimes which can be punished by imprisonment of 4 years and more) and in the interest of the police enquiry.

21 See Fijnaut 1987; Van der Kruijs 1995; Spronken 1997.

22 According to Articles 28 and $50 \mathrm{CCP}$ a suspect is entitled to legal assistance when he or she is arrested, but defence lawyers are usually permitted to speak to their clients only whilst their client is not being interrogated. When a suspect is detained for longer than 6 hours (or 15 hours where night-time is included), he or she has the right to legal assistance paid for out of public funds (Article $40 \mathrm{CCP}$ ). Even in these circumstances contact with the lawyer is denied during the course of police interrogation. As a result, only those who can afford to pay for a lawyer can exercise their right to legal advice during the first 6 (or 15) hours, and the right cannot be exercised at any time when the suspect is being interrogated. However, see the brief discussion of the case of Murray $v$ UK in note 1 .

23 Strictly, Code C paragraph 2.4 only gives the right to sight of the custody record on the lawyer's arrival at the police station, or after release of the suspect, although in practice custody officers will normally allow sight of the custody record on request.

24 Which in the Netherlands can be delayed for as long as three months from the date of the arrest, or even longer in certain circumstances.

25 See the Final Report of the Van Traa commission, p. 387 et seq. 
26 In England and Wales, failure to answer police questions may lead to adverse inference being drawn at trial by virtue of the Criminal Justice and Public Order Act 1994 sections 34-38. For an examination of the implications of these provisions for the defence lawyer advising at the police station see Cape 1995, esp. chapter 5. See also $R v$ Condron [1996] Crim LR 215. In the Netherlands the right to silence is considered absolute in the sense that failure to answer police questions cannot be used as evidence, but as in England and Wales, adverse inferences may be drawn at trial. See HR 12 March 1996, NJ 1996, 539 and HR 19 March 1996, NJ 1996, 540 and Spronken 1997.

27 In England and Wales PACE imposes time limits on detention without charge, initially of 24 hours. Although these may be extended, ultimately up to 96 hours on the authority of a court (or 7 days on the authority of the Home Secretary in terrorism cases), the grounds for doing so relate to the conduct of the police investigation rather than the requirements of the defence.

28 In $R$ y Condron [1996] Crim LR 215 the Court of Appeal confirmed that an assertion at trial that the defendant did not answer police questions on the advice of his lawyer was not a sufficient reason to prevent a court from drawing inferences from that failure.

29 For an examination of the extent to which criminal procedure in the two jurisdictions conforms to the two theories, see Brants and Field 1995. As discussed later, in England and Wales the respective duties of defence and prosecution to disclose information to the other prior to trial, having developed rapidly at common law during the late 1980 s and early 1990 s, are significantly affected by the Criminal Procedure and Investigations Act 1996.

30 A distinction is assumed between establishing guilt or innocence and establishing truth. The trial process and rules of evidence in both jurisdictions enable a factually guilty person to be found not guilty in a legal sense. For a brief discussion, see Ashworth 1996.

31 Corstens 1995, p. 58-69 and 634-642; HR 9 May 1995, NJ 1995, 672; HR 31 May 1994, NJ 1995, 29; Court of Appeal Amsterdam 1 December 1994, NJ 1995, 159; HR 19 December 1995, NJ 1996, 249 (Zwolsman).

32 None of the proactive methods of police investigation considered above is directly governed by statute except the interception of public telephones or post (although see note 8). See Brants and Field 1995, pp. 61-64. See also note 7.

33 (1861) 8 Cox CC 498.

$34 R v$ Sang [1980] AC 402.

35 Ibrahim $v R$ [1914] AC 599.

36 Section 78 provides that a court may exclude prosecution evidence if it appears that, having regard to all the circumstances, including the circumstances in which the evidence was obtained, the admission of the evidence would have such an adverse effect on the faimess of the proceedings that the court ought not to admit it.

37 See, for example, $R v$ Latif; $R v$ Shahzad [1996] 1 All ER 353. 


\section{Ed Cape and Taru Spronken}

38 [1996] 3 All ER 289.

39 Guidelines on the use of Equipment in Police Surveillance Operations (Home Office 1984), which require such operations to be authorized by the Chief Constable.

40 The court confirmed that, despite the European Convention on Human Rights, there is no right to privacy in English and Welsh law and, even if there were, evidence obtained in breach of it was nevertheless admissible (subject to section 78 PACE).

41 In the sense of lack of conformity with regulatory laws as opposed to breach of the general criminal law.

42 See, for example, $R \vee A l i$ (1991), The Times 19 February, and $R \vee$ Bailey and Smith [1993] 3 All ER 513.

43 See, for example, Connelly v DPP [1964] AC 1254 and $R$ v Humphrys [1977] AC 1. In $R v$ Beckford [1995] Crim LR 712 the Court of Appeal stated that the two main circumstances where the procedure could be used were (a) cases in which the court concludes that the defendant cannot receive a fair trial, and (b) cases where the court concludes that it would be unfair for the defendant to be tried.

44 [1996] 1 All ER 353; Crim LR 414.

45 Similar conclusions have been drawn in other cases involving proactive policing, Cf. $R v$ Horseferry Road Magistrates' Court exp Bennett [1994] 1 AC 42, where the defendant had been abducted and brought to the UK in contravention of extradition laws.

46 This is a basic rule of professional conduct. For England and Wales, see Practice Rule 1, (1996) The Guide to the professional Conduct of Solicitors (Seventh Edition), London: The Law Society, and for the Netherlands see Rule 5 of the Gedragsregels 1992.

47 For criticism of the lack of adversarialism displayed by many defence lawyers, see generally, McConville, Hodgson, Bridges and Pavlovic 1994.

48 The argument here is concerned with proactive policing. It is true that the courts do, with some frequency, exclude evidence under both section 76 and section 78 PACE, particularly where there has been a breach of the PACE Codes of Practice. However, as argued earlier, proactive policing methods do not normally lead to exclusion of evidence except where they are seen as a method of circumventing the protective provisions of PACE, particularly in relation to interrogation. See, for example, $R \vee$ Bryce [1992] Crim LR 728, and the first instance decision in the Colin Stagg case, in which the person suspected of involvement in a particularly gruesome murder was contacted by a female undercover police officer who proceeded to entice him into confessing by pretending that she obtained gratification from acts of sexual violence.

49 The atgument here ignores the possible impact of unlawful police activity on sentence. In $R v$ Sang [1980] AC 402 the House of Lords did aver that the fact that evidence was obtained by an agent provocateur could be taken into account 
in mitigation of sentence, but it is unclear whether the courts do take into account such factors with any consistency.

50 In the Netherlands written documents such as official reports drawn up by the police are admitted as evidence at the trial (Articles 338 and $339 \mathrm{CCP}$ ). According to a judgement of the Supreme Court on 20 December 1926, NJ 1927, 85, hearsay evidence may be used to found a conviction. This has had the effect that in practice the importance of the investigation at the trial has dwindled and that the file is the main source of evidence.

51 More likely in the Netherlands for the reasons set out earlier.

52 Corstens 1995, p. 650; Grapperhaus en Nieuwenhuys 1990; HR 25 October 1977, NJ 1978, 137; HR 17 May 1988, NJ 1989, 142; HR 22 September 1992, NJ $1993,57$.

53 See $R v$ Puddick (1865) $4 \mathrm{~F} \& \mathrm{~F} 497$ and $R v$ Banks [1916] 2 KB 621. See also the Code of Conduct of the Bar of England and Wales, Annex H, paragraph 11, and the Guide to the Professional Conduct of Solicitors (Seventh Edition), Principle 21.19. The Code for Crown Prosecutors paragraph 2.2 states that the duty of the Crown Prosecution Service is to ensure that all relevant facts are given to the court, but in practice this is not interpreted to include evidence that tends to undermine the prosecution case. See also McConville et al. 1991, esp. ch. 8.

54 See Attorney General's Guidelines on the disclosure of information and $R v$ Keane [1994] I WLR 747. This duty has been significantly weakened, in respect of cases where the investigation started on or after 1 April 1997, by Parts I and II of the Criminal Procedure and Investigations Act 1996.

$55 R v$ Davis [1993] 1 WLR 613. See now rules made under section 19 (2) Criminal Procedure and Investigations Act 1996.

56 See, for example, Taylor $v$ Anderson (1986) The Times October 21. Cf. $R v$ Horseferry Road Magistrates' Court exp Bennett (No 2) [1994] 1 All ER 289.

57 It is clearly established that it is for the defence to satisfy the judge that disclosure is necessary in order to establish his or her innocence. See $R v$ Hennessy (1978) $68 \mathrm{Cr}$ App R 419 and $R v$ Hallett [1969] Crim LR 462.

58 Court of Appeal Amsterdam 1 December 1994, NJ 1995, 159.

59 The authority to enter a building should be given by an examining magistrate and only if there is a reasonable suspicion of a crime (Article $97 \mathrm{CCP}$ ); see also Mols 1996.

60 HR 19 December 1995, NJ 1996, 249 (Zwolsman); Court of Appeal 's-Gravenhage 27 December 1995, NJ 1996, 338; District Court 's-Hertogenbosch 22 December 1994, NJ 1995, 164.

61 Court of Appeal Amsterdam 1 December 1994, NJ 1995, 159; Court of Appeal 's-Gravenhage 29 January 1996, NJ 1996, 413.

62 See $R v$ Khan (1996) The Times July 5 . Note also the implicit endorsement of illegal police action by the Home Office Circular (1984), 'Guidelines on the Use of Equipment in Police Surveillance Operations'. 
63 But only in the form of trespass to property, since the use of such methods is unregulated by law and the police are permitted to do anything unless it is prohibited by law. Ironically, when the legislation referred to in note 8 comes into force there will be a stronger argument that actions taken in breach of the new law will, therefore, be unlawful and should be excluded.

64 See $R v$ Johnson [1988] 1 WLR 1377, $R \vee$ Hewitt (1992) $95 \mathrm{Cr}$ App R 81, and Blake v DPP (1993) 97 Cr App R 169.

65 Failure to do so in these circumstances could be challenged by the defence if it was aware of its existence, and failure to comply with a court order to disclose, as where the tapes had already been destroyed, may result in the case being stayed for abuse of process. For an example, see $R v$ Birmingham and Others [1992] Crim LR 117, a Crown Court decision. For investigations commenced since 1 April 1997, the prosecution (if it did not intend to use the evidence at trial) would initially only have to disclose the evidence (subject to PII) if, in the view of the prosecution, it might undermine the prosecution case (section 3 Criminal Procedure and Investigations Act 1996).

66 See note 54 .

67 Under the Criminal Procedure and Investigations Act 1996, the defence could only apply to a court for disclosure of the video if it had disclosed the nature of the defence and could satisfy the court that it might assist the defence as disclosed in the defence statement.

68 HR 7 May 1996, NJB 1996, nr. 65; see also ECHR 16 December 1992 (Edwards), Series A, vol, 247-B.

69 District Court Rotterdam, 13 September 1995, NJ 1996, 343. This would include not only information that is relevant to the facts, but also to whether procedural rules have been satisfied, whether the means of securing evidence were lawful, and whether they were in accordance with Article 6 of the European Convention.

70 According to Article 152 of the Dutch Code on Criminal Procedure.

71 Inzake opsporing 1996, pp. 458-459.

72 In force, in respect of its disclosure provisions, from Spring 1997.

73 Although it can be argued that the right to silence provisions of the Criminal Justice and Public Order Act 1994 created strong pressure on the defence to disclose the nature of its defence at the interrogation stage in order to avoid adverse inferences from failure to do so.

74 As opposed to information which might undermine the prosecution case, which must be disclosed in any event in serious cases (but only if the defendant pleads not guilty in less serious cases) (Criminal Procedure and Investigations Act 1996 section 3(1)).

75 The admission of hearsay evidence and written statements as evidence at trial in the Netherlands has had the effect, in practice, that the significance of the trial for the assessment of evidence has declined. The records of police investigation, results of proactive policing such as records of observation activities and telephone tapping and statements made by witnesses to the police, are all laid down 
in a file, or dossier, which forms the most important source of evidence. The oral procedure of evaluating evidence at the trial mainly consists of the court reading out the written statements in the file and posing additional questions to the accused.

76 ECHR 20 November 1989, Series A, vol. 166.

77 Although the corroborating evidence does not have to corroborate directly the evidence of the anonymous witness, but may be other evidence of guilt.

78 ECHR 24 November 1986, Series A, vol. 110 (Unterpertinger); ECHR 6 December 1988, Series A, vol. 146 (Barberà); ECR 20 November 1989, Series A, vol. 166 (Kostovski); ECHR 27 September 1990, Series A, vol. 186 (Windisch); ECHR 19 December 1990, Series A, vol. 191 (Delta); ECHR 19 February 1991, Series A, vol. 194-A (Isgro); ECHR 26 April 1991, Series A, vol. 203 (Asch); ECHR 15 June 1992, Series A, vol. 238 (Lüdi).

79 ECHR 26 March 1996, 54/1994/501/583, Doorson v Netherlands, to be published in Reports of Judgements and Decisions for 1996.

80 ECHR 23 April 1997, nr. 55/1996/674/861-864 to be published in Decisions and Reports 1997.

81 [1979] AC 440.

82 Which, in the light of the earlier discussion, it is clear that they may not have to.

83 See, for example, $R v$ Setz-Dempsey (1994) $98 \mathrm{Cr}$ App R 23. The circumstances in which written statement may be adduced in evidence in a crown court trial are also, potentially, considerably widened by section 68 and Schedule 2 of the Criminal Procedure and Investigations Act 1996.

$84 \mathrm{As}$, for example, in the case of $R v$ Aubrey, Berry and Campbell, which led to the action against the journal that published the name of the anonymous witness. See Attorney-General v Leveller Magazine [1979] AC 440.

85 There is provision for evidence in certain cases to be given by pre-recorded video or by closed-circuit television, but these are confined to cases where the witness is a child or outside the UK. See sections 32 and 32A Criminal Justice Act 1988.

86 See $R$ ข DJX, SCY, GCZ (1989) $91 \mathrm{Cr}$ pp R 36.

87 [1993] Crim LR 388.

88 (1994) Times Law Reports 484.

89 By the Contempt of Court Act 1981 section 8.

90 See i.a. ECHR 24 April 1990, Series A, vol. 176 (Huvig and Kruslin).

91 ECHR 24 November 1993, Series A, vol. 275 (Imbrioscia) and ECHR 8 February 1996 (Murray), to be published in Reports of Judgements and Decisions for 1996.

92 Cf. the contributions of Jacobs 1988 and Jennings 1988.

93 See Garland v British Rail Engineering Ltd., [1983] 2 AC 751.

94 [1991] 1 AC 696. 
95 At p. 747. For a discussion of the impact of the ECHR decision of Murray $v$ United Kingdom, Case No 41/1994/488/570; (1996) The Times 9 February, see Munday 1996.

96 (1996) The Times 5 July. See also $R v$ Morrisey, $R$ v Staines (1997), The Times 1 May.

97 This is so whether the corruption is criminal in intent or what has been termed 'noble cause corruption'. It is interesting to note that the Interim Report of the New South Wales Royal Commission on the Police Service expressly disapproved of the term since process corruption, as it preferred to describe it, 'strikes at the very heart of the administration of the criminal justice system'.

98 The Police Act 1997 which gives statutory authority to the police in England and Wales to search property and place secret listening devices in the investigation of serious crime, defines serious crime to include those well outside the sphere of organized crime.

\section{References}

Ashworth, A. (1996), Crime, Community and Creeping Consequentialism, Criminal Law Review 220.

Audit Commission (1993), Helping with Enquiries: Tackling Crime Effectively, London: HMSO.

Baldwin, J. (1992), The Conduct of Police Investigations: Records of Interview, the Defence Lawyer's Role and Standards of Supervision, Research Studies Nos. 2, 3 and 4, The Royal Commission on Criminal Justice, London: HMSO.

Baldwin, J. (1993), Police Interview Techniques: Establishing Truth or Proof?, The British Journal of Criminology, (33) 3 Summer.

Bottomley, K., C. Coleman, D. Dixon, M. Gill and D. Wall (1991), The Impact of $P A C E$, Hull: University of Hull.

Brants, C. and S. Field (1995), Participation Rights and Proactive Policing: Convergence and Drift in European Criminal Process, Deventer: Kluwer.

Cape, E. (1994), Defence Services: What Should Defence Lawyers Do at Police Stations?, in: M. McConville and L. Bridges (eds.), Criminal Justice in Crisis, Aldershot: Edward Elgar.

Cape, E. (1995), Defending Suspects at Police Stations (Second Edition), London: Legal Action Group.

Cape, E. (1996), Getting to grips with police corruption, Legal Action July 8.

Corstens, G.J.M. (1995), Het Nederlands strafprocesrecht, Amhem: Gouda Quint.

Damaška, M.R. (1986), The Faces of Justice and State Authority, New Haven and London: Yale University Press. 
Dunningham, C. and C. Norris (1996), The nark's game, New Law Journal 402 and 456.

Enright, S. (1996), The anonymous witness, New Law Journal 1032.

Fijnaut, C. (1987), De toelating van raadslieden tot het politiële verdachtenverhoor, Antwerpen: Kluwer, Arnhem: Gouda Quint.

Gomien, D., D. Harris and L. Zwaak (1996), Law and Practice of the European Convention on Human Rights and the European Social Charter, Strasbourg: Council of Europe Publishing.

Grapperhaus, M.J. en J. Nieuwenhuys (1990), De gevolgen van onrechtmatige bewijsgaring, Nederlands Juristenblad, p. 769.

Inzake opsporing (1996), Eindrapport van de Enquêtecommissie Opsporingsmethoden 1 februari 1996, 's-Gravenhage: Sdu.

Jacobs, F.J. (1988), The Convention and the English judge, in: John Matscher and Herbert Petzold (eds.), Protecting Human Rights: The European Dimension, Köln: Carl Heymanns Verlag KG, pp. 273-279.

Jennings, Sir Robert (1988), Human Rights and Domestic Law and Courts, in: John Matscher and Herbert Petzold (eds.), Protecting Human Rights: The European Dimension, Köln: Carl Heymanns Verlag KG, pp. 295-300.

Klug, F., K. Starmer and S. Weir (1996), The Three Pillars of Liberty, London: Routledge.

Knigge, G. (1990), Van opsporing en strafvordering, Delikt en Delinkwent, pp. 195213.

Kruijs, P.M. van der (1995), Kanttekeningenbij de inverzekeringstelling,Advocatenblad 1995, p. 943.

Marx, G.T. (1988), Undercover: Police Surveillance in America, Berkeley: University of Califomia Press.

Matscher, J. and H. Petzold (eds.) (1988), Protecting Human Rights: The European Dimension, Köln: Carl Heymanns Verlag KG.

McConville, M., A. Sanders and R. Leng (1991), The Case for the Prosecution, London: Routledge.

McConville M. and J. Hodgson (1993), Custodial Legal Advice and the Right to Silence, Research Study No. 16, The Royal Commission on Criminal Justice, London: HMSO.

McConville, M., J. Hodgson, L. Bridges and A. Pavlovic (1994), Standing Accused: the organisation and practices of criminal defence lawyers in Britain, Oxford: Clarendon.

McKenzie, I., R. Morgan and R. Reiner (1990), Helping the Police with Their Inquiries: the Necessity Principle and Voluntary Attendance at the Police Station, Criminal Law Review 22.

Mols, G.P.M.F. (1996), Wie niet weg is gezien, Justitieel onderzoek in en rondom de woning, in: C.H. Brants, C. Kelk and M. Moerings, M. (eds.), Er is meer, Deventer: Gouda Quint, pp. 191-200. 
322 Ed Cape and Taru Spronken

Munday, R. (1996), Inferences from Silence and European Human Rights Law, Criminal Law Review 370.

Naeyé, J. (1995), Het politieel vooronderzoek in strafzaken, Amhem: Gouda Quint. Prakken, T. (1995), Interne openbaarheid in het strafprocesrecht; een bedreigd goed, Nederlands Juristenblad, pp. 1451-1458.

Roberts, P. (1995), Taking the Burden of Proof Seriously, Criminal Law Review 783.

Roos, Th.A. de (1991), Verdediging van belangen: het belang van verdediging, Arnhem: Gouda Quint.

Simmelink, J.B.H.M. (1987), De rechtsstaatgedachte achter art. 1 Sv., Arnhem: Gouda Quint.

Spronken, T. (1996), Nemo tenetur, zwijgrecht en advocatenbijstand bij het politieverhoor: de zaak Murray, Advocatenblad, pp. 420-424.

Spronken, T. (1997), in: C.P.M. Cleiren and J.F. Nijboer (eds.), Tekst \& Commentaar Strafvordering, Deventer: Kluwer.

The Law Society (1996), The Guide to the Professional Conduct of Solicitors (Seventh Edition), London: The Law Society. 